\title{
Genre features of applause. "As an example of Shukur Kholmirzaev's stories"
}

\author{
Mamayusupova Saodat Mamatqulovna ${ }^{1}$ \\ ${ }^{1}$ Jizzakh State Pedagogical Institute, Senior teache, Uzbekistan \\ Email: saodatmamayusupova78@gmail.com
}

\begin{abstract}
This paper makes analyses of the genre features of applause. On this case, ShukurKholmirzaev's stories were mentioned in order to make better illustration as the whole. Final, conclusions were stated to make better developments on different further investigation as well.
\end{abstract}

Keywords: Applause, genre, features, Shukur Kholmirzaev, stories, examples.

\section{INTRODUCTION}

From time immemorial, people regarded the word as a weapon of communication as something that has a supernatural power. This is because they have considered communication as a means of profit or harm to people. The main reason for this is that they did not properly understand the effect of the word on the human psyche. They believe that words can bring about health, happiness, employment, or success in war, or bring about unhappiness, death, or failure.

Seeing the supernatural power of the word caused the various words that have conflicting meaning in folklore. These include words like applause, cursing, spells, prayers. One of the most important features of the historical and folklore is the continuity of the revival, enrichment and improvement of oral masterpieces created by our ancient ancestors. During the historical and evolutionary development of this creative process, some genres retained their live performance, while some genres were forgotten and abandoned. While some genres of folklore, such as myths, are widely studied today as "relict genres," genres such as poems, fairy tales, legends, and legends only survive. In this respect, folklore incorporates the diverse national spiritual world of the public into his work. At the same time, it gives the reader a chance to get acquainted with the national traditions, rich vocabulary and all national principles. This phenomenon is manifested in various ways, from the formation of the modern Uzbek prose to the present day. One of the most widely used genres in Shukur Kholmirzaev's work is applause. The writer demonstrates his artistic power and character in stories such as "No Man's House", "Success", "Headphone", "Uzbek bobo", "The flying man", "We are late", "Ukki is singing".

\section{THEORITICAL BACKGROUND}

Applause plays a special role in revealing the character of the hero.

"Yes, my brother," the old man laughed casually. - Then he laughed and immediately pulled it away and said, "This is what happens when I build a house." - Recovering the boutique is from a man, the rest is a woman's job. - So he started laughing again: - We have some poets, your house is full of wheat - they praise her very much. "O man, worship a woman! Man, Honor Woman ... ' Need more encouragement from poor husbands? What did you say?

Now Komiljon started to laugh. At the same time, he shook his head, which was an indication of his submission to the mistress: yes, it is not good that a woman praises a man.

As you know, every nation has a good tradition. Praising a woman, describing a woman Honoring a woman is the main duty of a man. "Understand," smiled Komil. "But do you know that it really isn't?" Why do you think I am ... wise? We all know that women like to be applauded. Another important aspect of the applause is the fact that the artist approaches the story through a conversation between the woman and the Comil.

Applause is always played for practical purposes. Applause is not just for entertainment. 
The applause in one way or another is inextricably linked to a particular activity of people and is a direct component of that activity.

-Oh, live. And it will be! said Kismatillo and pulled away from the old man's shoulder. But she did not know where to kiss, and she pressed her temple on her temple. - Amen, all right! Do not let our land be lost. Sh-shotuts produce plenty of fruit ...- We started to smile at the door. - Our garden is very fruitful. Tomorrow, yes, in the morning Kayumjon will do an abrasion. Abrezka.-Ha-ha-yes ... I say, thank you grandfather, everything is overloaded, right? [Elections 3, page 247].

\section{MAIN PART}

According to the Uzbek tradition, one of the people gathered around the table usually applauds the older. It was not traditionally for a crowd of suppers to start eating applause. Thus, the applause is an important ring that gives the moral right to the beginning of the gathering. It turns out that the use of applause for direct practical purposes constitutes one of the most important genre symbols. In the stories of the writer above, a young man achieves this goal. Because our hero once intended to look like Roziq Grandpa and continue this tradition.

One of the most important genre features of public applause is that they are always focused on specific objects. Indeed, every applause performed is addressed to a specific person or group of people.

Yes, by the way, Shakir was brave and then ...

When we sit down. "Come on, come and live." It doesn't matter, I'll tell the old woman. ' Learn from their languages. Let Tashkent be healthy and proud... let's live a healthy life. [Elections Volume 2, page 246]

The admiration of Shokir, the old man's son, as a result of the fact that Adib Kismatillo hangs on the skirts and finally achieves the old man and the old man in order to get the garden.

As we know, the Uzbek people have a good tradition. According to this tradition, the construction of huge structures, excavation of canals and ditches, harvesting in the field was carried out by hashar. The crowds gathered in hashar do not begin without the praise of the hardworking elders who are respected by the people. At this time, the elders are applauding and letting evangelists go on, and intense work begins.

"Hashar, hashar," repeated the elder Eman. - By the name of the hashar. Now in all regions ...

"Yes, there is a hashish in the regions too. Television also says," said the old man ...

- Talk about it ... Good luck! Amen, "said the elder [Elective Volume 3, page 224]

It is one of the features of the genre that defines the nature and function of the hashish that the hashish people come to when they are allowed to do it.

The second is the ability to complete certain activities. While our people have a long tradition of not committing this work, the habit of not completing that work at the same time confirms our opinion.

At last, Abel grandfather, who had let down half of the meat on the plate, drank a few cups of green tea, and opened his hand.

- Amen, you always have such a dishwasher. Let it add to the profession. Be as good as a gardener. The hadiths of our Prophet (may Allah bless him and grant him peace) said: Your life will be long. "Here's the action - the grass saved you from death. If that was the case in the open field, you would see it ... Allahu akbar. - Others have joined the Fatah [Elections Volume 3, page 346]

Praises signify the completion of a particular activity. Our people have a long tradition of not starting a business without applause, but at the same time, there is a tradition of not completing it. For example, the custom of not eating applause after dinner is a confirmation of our opinion.

The applause was once a talented creator. However, these works of art have quickly spread to the masses, passed from mouth to mouth, from generation to generation, and have come to us, both ideological and artistic. It is a leading way of creating public applause and living among the people. It is also worth noting that the public's perception of the essence of creativity is the expression of the vision, aspirations and aspirations of the people based on the unconditional acceptance of the product of creation. Therefore, any work of art created by talented individuals is immediately universally accepted by the general public and has been enriched both meaningfully and formally for centuries.

-I will say so! "No, Kismatjon ... Yes, let's make a prayer first. Let us not lose our place." Let us enjoy each other's successes and accomplishments, share our concerns, and maximize each other's needs, and let's go for four! Amen [Elective Volume 3, page 272] 
Public opinion, individuality, opinion, desire, and judgment are the result of the personal opinion, opinion, desire and judgment of the individual (the speaker).

Appreciation was created long ago, in the days when our ancestors did not discover the writing, and the works of these creatures have reached us through the memory of the people.

The loquacious nature of the folklore genres as a livelihood of their genres also exudes diversity in their performances.

Folklore works are multivariate because they are created orally, because each oral product can be interpreted differently in different places.

As a result, there are several variants of each work.

Accordingly, they have an option. From this point of view, it is clear that this genre is a leading feature when we refer to people's applause.

The only applause they can get is when they meet together and meet each other, and the older person greets them.

"Amen!" The music teacher suddenly opened her hand. - Let the work be done for you!

"Thank you, brother," said Otbosar, also reciting a prayer. - You made a good prayer. I appreciate it.

"If you do, just give me a blessing," the teacher said. - Let's see and hear flowers picking flowers.

- Please ... [Elective Volume 2]

We can see in the story a more packed, fresh desire filled with the same applause.

Finally, the old man said:

- Let our unity be broken and be kind. Dry slander will save you from untimely death. Let our country be prosperous and give people justice!"

Or another appearance

... Finally, the end of the old age, that is:

- Amen, achieve your goals. Let our country be peaceful and prosperous. Travelers are excited when they say, "Let's run, as you have said," ... [Box 2, page 317].

\section{CONCLUSION}

In summary, the genre characteristics of folk applause can also be determined by the common features of folklore, such as orality, traditionalism, and duplication, and within these features the individual features of applause are manifested.

Traditional folklore is also a leading genre for applause. Thanks to this feature the meaningful and formative, ideological and artistic nature of the public applause, the system of images is inherited from generation to generation.

Folklore works are multivariate because they are created orally and live verbally. Because each piece of oral work can be interpreted in different places by different people.

As a result, there are several variants of each work. Accordingly, they are multivariate. Each oral word can be interpreted in different places by different people.

Thus, applause is an inseparable part of folk pedagogics, which helps to educate the younger generation in the spirit of the old generation, as a purely practical genre. The applause arouses great interest in how folklore reflects reality as an independent genre of folklore. In our view, applause reflects reality from a consistent ideological and artistic point of view. The appeals act as informants and the directness of the point of view ensures that the ideas expressed in the work are clearly targeted. The applause denies the reality only negatively and negatively. In addition, the apparent and effective conveyance of the expressed goodwill into the object is, to a certain extent, an art form of applause. Consequently, the applause of the people is fully combined with personal perfection and meaningful highness. Applause is always played for practical purposes. Appreciation is not limited to entertainment.

Thus, the positive material of the reality chosen for applause will have a powerful effect only when expressed in a particular artistic form. Because applause is always created with the people's high ideals and feelings for beauty.

Throughout their lives, people are taught to apply applause, look at it with salvation, and most importantly, to feed the young generation with hope for the good, and to focus on the good.

Appreciation given by Shukur Kholmirzaev's stories fully confirms our point. 


\section{REFERENCES}

1. N.Kuchkarov genre and art of Uzbek folk applause. Nomz.diss., Tashkent, 1994.

2. Shukur Kholmirzaev Elections Volume 2, Tashkent, 2009, Sharq Publishing House

3. Shukur Kholmirzaev Elective Volume 3, Tashkent, 2005 Publishing and printing joint-stock company "Sharq" 